\title{
Competitiveness of Indonesian Small and Medium Food Processing Industry: Does the Location Matter?
}

\author{
Mukhamad Najib (Corresponding author) \\ Department of Agriculture and Resource Economics, The University of Tokyo \\ 1-1-1-321B Yayoi, Bunkyo-ku, Tokyo 113-8657, Japan \\ Tel: 81-3-5841-5321_E-mail:mnajib23@yahoo.com \\ $\&$ \\ Department of Management, Faculty of Economics and Management \\ Jl. Kamper Wing 2 Lantai 5, Kampus IPB darmaga, Bogor 16680, Indonesia
}

Tel: 62-251-8626520

Akira Kiminami

Department of Agriculture and Resource Economics, The University of Tokyo

1-1-1-321B Yayoi, Bunkyo-ku, Tokyo 113-8657, Japan

Tel: 81-3-5841-5321 E-mail: akira@mail.ecc.u-tokyo.ac.jp

Hironori Yagi

Department of Agriculture and Resource Economics, The University of Tokyo

1-1-1-321B Yayoi, Bunkyo-ku, Tokyo 113-8657, Japan

Tel: 81-3-5841-5321 E-mail: ayouken@mail.ecc.u-tokyo.ac.jp

Received: April 15, $2011 \quad$ Accepted: June 24, $2011 \quad$ doi:10.5539/ijbm.v6n9p57

\begin{abstract}
In this paper, we compare the competitiveness between clustered and dispersed Small Medium Enterprises (SMEs) in Indonesian food processing industry. This study was driven by the important role of SMEs in Indonesian food processing industry for helping low income people access the low price foods. Furthermore, as Indonesian Government implements policy that support clustered SMEs, it could be expected that SMEs in the cluster area could pursue and emphasize different performance than their non clustered counterparts. Primary data was collected in West Java, Indonesia. The sample includes only companies with fewer than 100 employees and those operate in the food processing industry. We put market orientation, innovation, and business performance as proxy of competitiveness. Mean comparison statistics was used to compare market orientation, innovation and business performance of clustered and dispersed SMEs. The main findings were found through data analysis notably there was significant difference between clustered and non clustered SMEs in market orientation, innovation and business performance.
\end{abstract}

Keywords: Market orientation, Innovation, Competitiveness, Cluster, Small medium enterprises, Food processing, Indonesia

\section{Introduction}

Several problems of Indonesian small and medium food processing industry such as capital, market access, and technology make them difficult to develop competitiveness. The level of competitiveness can be indicated from the performance (Grant, 1996). Many researches argue that performance is affected by market orientation (Kohli and Jaworski, 1990; Kara et all., 2005; Narver and Slater, 1990). Meanwhile, in the food sector, innovation is considered as one of the most important factors to enhance competitiveness (Gruner et al., 1996; Rama, 1996). Moreover, Liao and Rice (2010) said that firm performance can only be improved by innovation when they are accompanied by concrete and effective changes to the market presence of a firm (in response to market dynamic and customer demand). In other word, innovation and market orientation should go together in order to develop 
competitiveness.

Cluster can be considered as one of the important sources for improving competitiveness of SMEs due to its potential for facilitating the development of market oriented and innovative behavior. Researches show that companies in the cluster area get benefit due to easy for getting supplier and buyer (Stuart, 1979), have greater ability to access larger local market (Krugman, 1991), and they are encouraged to be more innovative because there are rivalry among companies in the cluster (Porter, 1990). Moreover, Braun and Hadwiger (2011) said that the proximity to research centers like universities that occur in the cluster are considered important for the survival of SMEs.

Indonesia has a long experience in applying the cluster concept, in which Indonesian cluster have been taking place since 1969-1970 by SMEs. Based on the report of ministry of cooperative (2007), in 1996, there were 9800 clusters of SMEs in Indonesia. Some of them are traditional industry in craft, food processing, iron, and so forth. Clustering policy in Indonesia has been followed by financial and technical assistance as an expression of the government seriousness to develop SMEs. Implementation of industrial cluster is expected to improve competitiveness and performance of SMEs, therefore the existence of cluster ideally can improve innovation of SMEs.

Study about SMEs cluster in Indonesia had been done by several researchers. For instance Burger et al. (2001) describe clustering of small agro-processing firm in Indonesia. In his study, he used palm sugar industry cluster as case study. Tambunan (2008) briefs us regarding the role of government in technology transfer to SME clusters in Indonesia. His study provides micro-level evidence from the Metalworking industry cluster in Central Java Indonesia. Paper written by Sato (2000) analyses forward linkages formed by small firm. Using rural metal-casting cluster in Central Java, He examines the effects of these linkages in promoting the firms' development.

However, the role of location factor is still questioned by researchers (e.g. Lublinski, 2003). In a globalized world where distance seems to be no longer an obstacle, as capital, knowledge, and other resources travel almost freely and at high speed location factors seems less important than before. Moreover, a weakness in cluster studies in Indonesia has been the lack of detailed counterfactual analysis. The question is how we can believe that companies located in the cluster have better competitiveness if we have no comparison with companies located out of cluster. This study seeks to fill this gap by comparing clustered and dispersed SMEs in the Indonesian food processing industry. The role of location can be seen clearly when we are able to present competitiveness comparison between clustered and non clustered SMEs at the same time.

In this paper we would like to investigate the performance of SMEs in the cluster of food processing industry by comparing them with dispersed SMEs in the same industry. Specifically, the objective of this paper is to compare SMEs in the cluster and non cluster in terms of market orientation, innovation and business performance as a proxy of competitiveness.

This paper contributes to the cluster and SMEs literature in two respects. First, we provide the comparative empirical data for further discussion regarding the role of location factor in improving competitiveness of SMEs in the food processing industry. Such kind of contribution is important due to comparative study between clustered and dispersed SMEs in food processing industry still rare. Second, this study is the first study that comparing clustered and dispersed SMEs in Indonesian food processing industry. As an emerging market, Indonesia, with a population of 240 million, is the world's fourth largest nation in terms of people. It has become not just one of the world's fastest-growing countries but also an interesting place for exploring business and economics theory.

\section{Theoretical Background and Hypotheses}

\subsection{Industrial Cluster}

Anderson (1994) defines industry cluster as a group of companies that rely on an active set of relationships among themselves for individual efficiency and competitiveness. According to Porter (2008), a cluster is a geographically proximate group of interconnected companies and associated institutions in a particular field, linked by communalities and complementarities. He describes cluster as networks of companies, suppliers, services firms, academic institutions and organizations in related industries that, together, bring new products or services to the market. Yingming (2010) says that industrial clusters are industrial aggregations formed by industrial sectors with close economic links in a specific territory. In addition, Yingming (2010) mentions that close economic links are not only the basic condition for forming industrial cluster, but are also important characteristics of industrial clusters.

Long and Zhang (2011) argues that the literature on clustering has highlighted at least three key positive externalities of industrial clusters: better access to the market and suppliers, labor pooling, and easy flow of technology know-how. However, they argue that the main advantage of clustering in developing countries with limited financial development is in helping firms alleviate financial constraints. Meanwhile Glaeser and Gottlieb (2009) emphasize the role of agglomeration in speeding the flow of ideas. Porter (1990) postulates that firms in clusters may be benefited from strong local rivalry, which may positively influence productivity and innovation 
performance. Firms in clusters may also benefit from relatively sophisticated and demanding local customers that push them to meet high standards in terms of product quality, feature and service. And demanding local customers may help to increase suppliers' motivation. To Von Hippel (1988) geographic proximity may enlarge the window to the market allowing for better access to customer information. With these positive externalities, Porter (1990) argues that clustering is an important way for firms to fulfill their competitive advantage.

Although the term of cluster becomes more popular recently, there is no single or standard model of cluster (Aylward and Glynn, 2005). Rather, each country and region has a different set of clusters, shaped by historical background, national characteristics, the strength of the knowledge base, size, connectedness, and share of innovative products. In Indonesia, areas called sentras are comprised of usually more than 20 SMEs (Tambunan, 2005); the sentra is a concept similar to cluster, as it is defined as a geographical concentration of manufacturers in the same sector. The working definition of clusters in this research is represented by sentra, which is a geographical concentration of related industries and institutions that link each other.

\subsection{Market Orientation and Innovation}

Narver and Slater (1990) define market orientation as the organization culture that most effectively and efficiently creates the necessary behaviors for creation of superior value for buyers and, thus, continuous superior performance for business. Market orientation is a construct with several dimensions. Following Narver and Slater (1990), market orientation is composed of three components: customer orientation (understanding customers' needs and wants), competitor orientation (understanding rivals' strengths and weaknesses and how they satisfy their customers' needs and wants), and inter-functional coordination (the firm-wide use of the organization's resources in creating superior customers' value).

The previous research that predicted a positive relationship between market orientation and performance was using the assumption that a market orientation provides a firm with a better understanding of its environment and customers. Some empirical studies found a positive relationship between market orientation and managers' perceptions of overall firm performance (Jaworski and Kohli 1993), managers' perceptions and financial performance (Pelham and Wilson 1996; Slater and Narver 1994), and managers' perceptions and new product performance (Atuahene-Gima 1996, 1995; Pelham and Wilson 1996; Slater and Narver 1994). At the same time, several studies did not support a direct positive relationship between performance and market orientation (Han et al., 1998; Jaworski and Kohli 1993). A possible explanation for the lack of clear relationship with market orientation is that it is a more complex relationship than those tested for in previous studies (Pelham 1997).

However, market-orientated firms have been demonstrated to be successful at maintaining a strong competitive position (Wang, et al. 2011). It occurs because of market-oriented behavior lead the firms to be more innovative. Johnston et al. (2011) argue that market-oriented firms are strategically and tightly aligned with the market in such a way that they are able to put their customers' expressed needs when creating new product. Research shows that number of SMEs in manufacturing industries have survived and thrived through the release of innovative new products (Laforet, 2008). Therefore, Slater and Narver (1994) suggest that innovation and new product success are intermediates for the relation between market orientation and business performance. Further, Han et al. (1998) empirically established that market orientation facilitates organizational innovation, as measured in terms of the absolute number of both technical and administrative innovations implemented. Many studies that focus on factors discriminating between successful and unsuccessful innovations conclude that market orientation is one of the main contributing factors to innovation success (Cooper, 1979).

\subsection{Innovation and Performance}

Innovation in the food processing industry is a rather complex process and can involve different parts throughout the food system, from the development of new ingredients to the formulation of new food products, from the improvement of methods of food preservation to new ways of packaging (Earle, 1997). Besides, each firm can be involved at different stages, from basic research up to market penetration with new products to gain competitive advantage over other firms (Hollenstein, 1996).

Raymond and Pierre (2010) argue that innovation is a concept that has been defined and characterized in many ways by researchers. Innovation, according to Verhees and Meulendberg (2004) can be defined as the process of developing a new item, the new item itself, and the process of adopting new item. In a small firm, innovativeness implies a willingness of the owner to learn about and to adopt innovation, both in the input and output markets. Forsman (2010) defines innovation as the generation and implementation of new or improved processes, services, products, production methods or single actions aimed at increasing the competitiveness of enterprise.

According to Sundbo (2003), there are various types of innovation and innovative activity, such as product innovation, process innovation, and market innovation. He explained that product innovation refers to the introduction of a new product to the market. Process innovation refers to the introduction of new production processes such as those enabled by new technology or new work routines. Market innovation denotes a firm's new market behavior such as a new strategy, new marketing, new alliance and so forth.

Parrilli and Elola (2011) argue that competitiveness is guaranteed by innovation and quality upgrade. A study by Deshpande et al. (1993) indicates that innovativeness is positively related to organizational performance in terms 
of relative profitability, market share, and growth. Baldwin and Johnson (1996) show the significant impact of innovation on a wide variety of business performance measures, including market share and return on investment. Salavou (2002) also found that product innovation was a significant determinant of business performance based on Return on Assets. Further, in the food sector, innovation is a strategic factor for the firm since it allows reduction in production costs and/or a better response to the needs of consumers who increasingly require enhance food products with service components and technological processing characteristics, such as quality, safety, ease of use, and storability (Capitanio, et al., 2010).

\subsection{Research Model and Hypotheses}

Based on the literature above we suggest that performance of SMEs in the food processing industry is affected by innovation. We agree that innovation is the one of the most important factor to enhance competitiveness either in small companies or in large companies due to in many cases product of SMEs also competes with product of large companies. Market orientation (customer orientation, competitor orientation, and inter-functional coordination) will affect innovation due to market oriented companies usually always monitor their customers' needs and wants, at the same time they have to deal with competitors better. In order to satisfy their customer and compete with competitors, companies should develop innovative product base on the customers' needs and wants.

Figure 1 explains the relationship between market orientation, innovation and business performance. We posit market orientation and innovation as source of competitiveness in which competitiveness as postulated by Grant (1996) can be indicated by business performance. To explore the role of location, we would like to compare sources of competitiveness (market orientation and innovation) and competitiveness (business performance) between SMEs food processing located in the cluster and SMEs located outside cluster.

We developed three general hypotheses based on the objective of this study mentioned before. The hypothesis is intended to examine the difference of cluster and non cluster SMEs in terms of business performance, innovation and market orientation. The overall hypotheses are described as follow:

- H1: There are mean difference in business performance between clustered and dispersed SMEs food processing industry.

- H2: There are mean difference in innovation between clustered and dispersed SMEs food processing industry.

- H3: There are mean difference in market orientation between clustered and dispersed SMEs food processing industry.

\section{Material and Methods}

\subsection{Sample and Data Collection}

To analyze the differentiation between clustered and dispersed SMEs food processing in Indonesia, we did survey on SMEs food processing located in cluster and dispersed. For clustered SMEs, we collected data from SMEs food processing industry in five clusters located in West Java. Firstly, we decided five clusters which represent food processing industry in West Java, that are (1) milk cluster located in Pengalengan District, (2) emping melinjo crackers cluster located in Cianjur District, (3) tempe cluster located in Bandung District, (4) processed fish cluster located in Cianjur District, and (5) tapioca flour cluster located in Bogor District. Sample was taken from each cluster proportionately depend on the number of firm in each cluster and depend on the willingness of managers or owners of firm to be interviewed. For dispersed SMEs, we collected data from SMEs food processing industry located far from cluster area but at the same district.

The respondents involved in this research comprised of 120 managers and owners who had knowledge of past and present organization practices comprehensively, particularly with regards to market orientation, innovation, and business performance. Off 120 respondents, 60 respondents were collected from cluster area and the rest was collected from outside cluster. Sample needed in this research should fulfill several criteria. First, SMEs should be located both in cluster and non cluster area. This consideration had been taken in accordance with the research objectives, i.e., to compare clustered and dispersed SMEs food processing. Second, the sample includes only companies with fewer than 100 employees and those which operate exclusively in the food processing industry. We categorized SMEs based on the number of employees that complies with the definition of SMEs provided by the Ministry of Cooperatives and Small and Medium Enterprises of Indonesia. Third consideration was the ease with which data could be obtained, as not all the company owners could be interviewed or wished to participate in this study.

\subsection{Measurements Data Analysis}

Business performance is operationalized as a composite of three measures; sales volume, market share and profitability. To measure business performance, we used the subjective measurement method. This method was selected due to SMEs in Indonesia generally have no good and consistent records, especially monthly and yearly record of finance and production. By such condition, it was better to use subjective measurement to measure performance instead of objective measurement. Moreover, a study by Dawes (1999) shows that there is a 
positive correlation between subjective performance measures and objective performance measures.

To measure market orientation, we adapted measurement model developed by Narver and Slater (1990), which has been used in a variety of market orientation studies (e.g., Gatignon and Xuereb, 1997; Han et al., 1998; Lukas and Ferrel, 2000). They identify three components of market orientation: customer orientation, competitor orientation, and inter-functional coordination. In this research, we used term internal coordination instead of inter-functional coordination due to our object of study is SMEs. With small number of employee it is difficult for SMEs to separate their employee in many functions strictly.

The concept of innovation used in the survey is rather broad. It includes both small improvement in product, processing techniques and marketing strategy and more radical changes such as the introduction of new products, processes and marketing strategies. To measure innovation, we adapted three types of innovation defined by Sundbo (2003), i.e., product innovation, process innovation, and marketing innovation. To compare clustered and dispersed SMEs, we did mean comparison analyses.

\section{Results and Discussion}

\subsection{Profile of Clustered and Dispersed SMEs}

In this section we would like to describe characteristics of respondents in this research and comparing those who are located in the cluster and outside cluster. There are several characteristics that are compared in this section, notably sources of working capital, marketing area, types of customer, and human resource development.

In terms of working capital, both of clustered and dispersed SMEs have the same characteristic related to independency. In figure 2 we can see that all of SMEs use their own money as one of sources of working capital. Besides using their own money, they also receive working capital from other sources such as Bank, Government and Cooperative. However, SMEs in the cluster area are able to utilize external sources of working capital better than dispersed SMEs.

Regarding marketing area, both of clustered and dispersed SMEs food processing in West Java serves local market. For regional and national market, clustered SMEs have larger percentage than dispersed SMEs. Of 75\% SMEs in the cluster serve regional market meanwhile the only 50\% dispersed SMEs serve regional market (see figure 3). This result also shows that there are no SMEs in West Java that are able to serve international market.

SMEs food processing in the cluster and non cluster area has various types of customer from agent to end users. Products of SMEs are also consumed by other companies in which they use SMEs products as raw material for their production process. In general, SMEs in the cluster and non cluster area relatively have similar types of customer (see figure 4).

\subsection{Clustered and dispersed SMEs: the Performance Gap}

This section contains empirical evidence on performance differences between clustered and dispersed SMEs in Indonesian food processing industry. We argue that clustered SMEs must be better in term of business performance compare than their dispersed SMEs counterpart. It is because clustered SMEs receive more support from government and also geographic proximity among SMEs create many opportunity for SMEs to improve their performance.

As illustrated in table 1, there are significant difference between clustered and dispersed SMEs in terms of sales, market share and profit. We can say that these three performance indicators show the performance gap between clustered and dispersed SMEs. Hypothesis 1 predicts that there are mean difference in business performance between clustered and dispersed SMEs. This research result supports hypothesis 1 . Therefore, this result of study also makes us clear that clustered SMEs have higher performance compare to non clustered SMEs.

The research result in line with another study related to cluster (i.e. Anderson, 1994; Folta et al., 2006; Waits, 2000). Even though SMEs food processing in Indonesia has many problem such as mentioned before (i.e. lack of capital and market access), joint in the cluster make them better for improving their business performance. This study result approves previous studies that cluster has positive impact on performance (i.e. Anderson, 1994; Folta et al., 2006; Waits, 2000), and completing them by provides comparative evidence between cluster and non cluster SMEs.

However, we still need more explanation about the factors influence the performance gap between cluster and non cluster SMEs. Following the positive relationship between market orientation, innovation and business performance, we would like to investigate whether there are also the gap in market orientation and innovation between clustered and dispersed SMEs.

\subsection{Market Orientation and Innovation Gap}

After observing the performance gap between clustered and dispersed SMEs, the question is whether this is (mainly) due to market orientation or innovation activities. In this section we observed the different level of market orientation and innovation between clustered and dispersed SMEs. This observation will answer the question why clustered SMEs have better performance than dispersed SMEs.

Porter (2008) argues that SMEs in the cluster area tend to consider other companies within cluster as a rival. It 
makes them always aware about competitor strength, weakness and strategy. At the same time they compete for getting the same customer. It leads them to understand their customer's need and want and try to satisfy their customer's need and want. We argue that such kind of behavior will improve their level of market orientation. Therefore, we posit in hypothesis 2 that predicts there are mean difference in market orientation between clustered and dispersed SMEs. As can be seen in table 2, two components of market orientation (customer orientation and competitor orientation) are significantly different between clustered and dispersed SMEs. In this case clustered SMEs have higher level of customer orientation and competitor orientation than dispersed SMEs. However, in terms of internal coordination, there is no significant difference between clustered and dispersed SMEs. Probably it is because the small number of employee does not make any difference in coordination activities between clustered and dispersed SMEs.

Eisingerich at al. (2009) suggest companies that integrate and expand information flow may benefit from more effective coordination of actions and consequently higher product innovation performance. We are in the same line with their suggestion in which we argue that cluster will benefit SMEs for innovating. Therefore in hypothesis 3 we predict that there are mean difference in innovation between clustered and dispersed SMEs. Table 2 shows that clustered and dispersed SMEs have significant difference in term of product innovation, process innovation and marketing innovation. It means that hypothesis 3 is confirmed by this study. In this case we can see that clustered SMEs have higher level of innovation than dispersed SMEs.

This study has been completing previous study about the role of industrial cluster in increasing innovation (i.e. Aylward \& Glynn, 2005; Porter, 2008; Tambunan, 2005) by providing empirical data in small and medium food processing industry. In this study we mentioned that high level of innovation in cluster area is affected by market orientation. As mentioned above market orientation is determinant factor of innovation. Since market orientation in clustered SMEs is higher than dispersed SMEs, innovation level in clustered SMEs is also higher than dispersed SMEs.

\section{Managerial and policy implication}

The findings of the present research have interesting managerial implications. First, location factor has an important role in creation competitiveness of SMEs food processing in Indonesia. The different level of business performance between clustered and dispersed SMEs may indicate the matter of location. Although globalization make location seems useless due to resources can be transported freely from one place to another, these research findings confirm that in the developing country context like Indonesia geographic proximity among SMEs produce much benefit.

These findings suggest that geographic proximity such as cluster area will benefit SMEs for improving their market orientation and innovation. In the past, new product development was mainly determined by individual companies' capabilities to collect and understand information about their customers and competitors. However, as competition has gradually shifted from among individual integrated firms to among clustered networks of organizations, a firm's market orientation, as defined by Kohli and Jaworski (1990), not only affects the company's responsiveness to competition and customer needs but can impact the entire network of companies it is part of. This is because individual companies can learn from, and take advantage of, each other's marketing orientation skills.

Since government of Republic of Indonesia has been implementing cluster concept for SMEs, they should pay attention with the positive relationship between market orientation, innovation and business performance. The policy for improving business performance in cluster of SMEs should consider market orientation and innovation as the determinant factors of business performance. It means that certain policy that will be implemented in the cluster of SMEs should be directed to improve market oriented and innovative behavior.

Cluster area can be one of the most important sources of competitive advantage for SMEs in the Indonesian food processing industry. Indonesia has abundance of less competitive SMEs located out of cluster. Promoting cluster policy for improving SMEs competitiveness in Indonesia can be one solution. Of course it is not easy due to relocation of SMEs in one area like cluster may need high initial investment, so that cost and benefit of this policy should be calculated carefully.

\section{Conclusion}

This study has addressed the important consideration when comparing performance, market orientation and innovation between clustered and dispersed SMEs in Indonesian food processing industry. The findings indicate that business performance in clustered SMEs is significantly different than that in dispersed SMEs. Other findings indicate that market orientation and innovation level in clustered SMEs is significantly higher than that in dispersed SMEs. By these findings, basic hypotheses (there are mean difference between clustered and dispersed SMEs) that are proposed in this study are proven.

Location factor, in this case is cluster and non cluster, has influence on competitiveness. Such conclusion has been confirmed by the fact that cluster give positive condition for developing market orientation and innovation in which SMEs in the cluster area can perform better than dispersed SMEs. 
However, there are several limitations inherent in this research. First, this study did not consider the distance between clustered and dispersed SMEs location. It is possible for dispersed SMEs located nearby cluster receive benefit from the cluster. Second, the number of sample is relatively small if we consider generalizing this result of study. Additional research could complement this study with a larger regional sample to enhance the generalizability of these results. Longitudinal design may also provide insight into the long-term impact of cluster in improving competitiveness of SMEs food processing industry.

\section{References}

Anderson, G. (1994). Industry Clustering for Economic Development. Economic Development Review, 12 (2), 26-32.

Atuahene-Gima, K. (1995). An Exploratory Analysis of the Impact of Market Orientation on New Product Performance. Journal of Product Innovation Management, 12, 275-293. doi:10.1016/0737-6782(95)00027-Q, http://dx.doi.org/10.1016/0737-6782(95)00027-Q

Atuahene-Gima, K. (1996). Market Orientation and Innovation. Journal of Business Research, 35, 93-103. doi:10.1016/0148-2963(95)00051-8, http://dx.doi.org/10.1016/0148-2963(95)00051-8

Aylward, D., \& Glynn, J. (2005). Assessing SME Innovation within Different Cluster Models: Lesson from the Australian Wine Industry. Proceedings of the 18th Annual Conference of SEAANZ. New England: University of New England.

Baldwin, J. R., \& Johnson, J. (1996). Business Strategies in more- and less-Innovative Firms in Canada. Research Policy, 25(5), 785-804. doi:10.1016/0048-7333(95)00875-6, http://dx.doi.org/10.1016/0048-7333(95)00875-6

Braun, S., \& Hadwiger, K. (2011). Knowledge Transfer from Research to Industry (SMEs)-An Example from the Food Sector. Trend in Food Science \& Technology, doi:10.1016/j.tifs.2011.03.005, http://dx.doi.org/10.1016/j.tifs.2011.03.005

Burger, K., Kameo, D., \& Sandee, H. (2001). Clustering of Small Agro-Processing Firms in Indonesia. International Food and Agribusiness Management Review, 2 (3/4), 289-299.

Capitanio, F., Coppala, A., \& Pascucci, S. (2010). Product and Process Innovation in the Italian Food Industry. Agribusiness, 26(0), 1-16.

Cooper, R.G. (1979). The Dimensions of Industrial New Product Success and Failure. Journal of Marketing, 43(2), 93-103. doi:10.2307/1250151, http://dx.doi.org/10.2307/1250151

Dawes, J. (1999). The Relationship between Subjective and Objective Company Pperformance Measures in Market Orientation Research: Further Empirical Evidence. Marketing Bulletin, 10(3), 65-75.

Deshpande, R., Farley, J. U., \& Frederick E. Webster, J. (1993). Corporate Culture, Customer Orientation and Innovativeness in Japanese Firms: A quadrad analysis. Journal of Marketing, 57, 23-27. doi:10.2307/1252055, http://dx.doi.org/10.2307/1252055

Earle, M.D. (1997). Innovation in the Food Industry. Trends in food science and technology, 8(5), 166-175. doi:10.1016/S0924-2244(97)01026-1, http://dx.doi.org/10.1016/S0924-2244(97)01026-1

Eisingerich, A.B., Rubera, G., \& Seifert, M. (2009). Managing service innovation and interorganizational relationships for firm performance: To commit or diversify? Journal of Service Research, 11(4), 344-356. doi:10.1177/1094670508329223, http://dx.doi.org/10.1177/1094670508329223

Folta, T. B., Cooper, A. C., \& Baik, Y. S. (2006). Geographic Cluster Size and Firm Performance. Journal of Business Venturing, 21(2), 217-242. doi:10.1016/j.jbusvent.2005.04.005, http://dx.doi.org/10.1016/j.jbusvent.2005.04.005

Forsman, H. (2011). Innovation Capacity and Innovation Development in Small Enterprises. A Comparison between the Manufacturing and Service Sectors. Research Policy, 40(5), 739-750. doi:10.1016/j.respol.2011.02.003, http://dx.doi.org/10.1016/j.respol.2011.02.003

Gatignon, Hubert \& Jean-Marc Xuereb. (1997). Strategic Orientation of the Firm and New Product Performance. Journal of Marketing Research, 34, 77-90. doi:10.2307/3152066, http://dx.doi.org/10.2307/3152066

Glaeser, E.L., \& Gottlieb, J.D. (2009). The Wealth of Cities: Agglomeration Economies and Spatial Equilibrium in the United States. Journal of Economic Literature, 47(4), 983-1028. doi:10.1257/jel.47.4.983, http://dx.doi.org/10.1257/jel.47.4.983

Grant, R.M. (1996). Prospering in dynamically competitive environments: Organizational capability as knowledge integration. Organization Science, 7(4), 375-387. doi:10.1287/orsc.7.4.375, http://dx.doi.org/10.1287/orsc.7.4.375

Grunert, K., Hartvig Larsen, H., Madsen, T.K., \& Baadsgaard, A. (1996). Market Orientation in Food and Agriculture. Boston: Kluwer.

Han, J. K., N. Kim, \& R. K. Srivastava. (1998). Marketing Orientation and Organizational Performance: Is 
Innovation a Missing Link? Journal of Marketing, 62, 30-45. doi:10.2307/1252285, http://dx.doi.org/10.2307/1252285

Hollenstein, H. (1996). A Composite Indicator of Firm's Innovativeness: An Empirical Analysis Based on Survey Data for Swiss Manufacturing. Research Policy, 25(4), 633-645. doi:10.1016/0048-7333(95)00874-8, http://dx.doi.org/10.1016/0048-7333(95)00874-8

Jaworski, Bernard J., \& Ajay K. Kohli. (1993). Market Orientation: Antecedents and Consequences. Journal of Marketing, 57, 53-70. doi:10.2307/1251854, http://dx.doi.org/10.2307/1251854

Johnston, E.Z., Darroch, J., \& Matear, S. (2011). Business Orientations and Innovation in Small and Medium Sized Enterprises. International Entrepreneurship and Management Journal. doi:10.1007/s11365-011-0170-7, http://dx.doi.org/10.1007/s11365-011-0170-7

Kara, Ali, John E. Spillan, \& Oscar W. DeShields, Jr. (2005). The Effect of a Market Orientation on Business Performance: A Study of Small-Sized Service Retailers Using MARKOR Scale. Journal of Small Business Management, 43(2), 105-118. http://dx.doi.org/10.1111/j.1540-627x.2005.00128.x doi:10.1111/j.1540-627x.2005.00128.x,

Kohli, Ajay K., \& Bernard A. Jaworski. (1990). Market Orientation: The Construct, Research Propositions, and Managerial Implications. Journal of Marketing, 54(2), 1-18. doi:10.2307/1251866, http://dx.doi.org/10.2307/1251866

Krugman, P. (1991). Increasing Returns on Economic Geography. The Journal of Political Economy, 99 (3), 483-499. doi:10.1086/261763, http://dx.doi.org/10.1086/261763

Laforet, S. (2008). Size, Strategic, and Market Orientation Affects on Innovation. Journal of Business Research, 61(7), 753-764. doi:10.1016/j.jbusres.2007.08.002, http://dx.doi.org/10.1016/j.jbusres.2007.08.002

Liao, T.S., \& Rice, J. (2010). Innovation Investments, Market Engagement and Financial Performance: A Study among Australian Manufacturing SMEs. Research Policy, 39, 117-125. doi:10.1016/j.respol.2009.11.002, http://dx.doi.org/10.1016/j.respol.2009.11.002

Long, C., \& Zhang, X. (2011). Cluster-based Industrialization in China: Financing and Performance. Journal of International Economics, 84(1), 112-123. doi:10.1016/j.jinteco.2011.03.002, http://dx.doi.org/10.1016/j.jinteco.2011.03.002

Lublinski, A.E. (2003). Does Geographic Proximity Matter? Evidence from Clustered and Non Clustered Aeronautic Firms in Germany. Regional Studies, 37, 453-467. doi:10.1080/0034340032000089031, http://dx.doi.org/10.1080/0034340032000089031

Lukas, Brian A., \& O.C. Ferrel. (2000). The Effect of Market Orientation on Product Innovation. Journal of the Academy of Marketing Science, 28(2), 239-247. doi:10.1177/0092070300282005, http://dx.doi.org/10.1177/0092070300282005

Ministry of Cooperative and Small and Medium Enterprises. (2007). Final Report of Study on Cluster Growth Affectivity Model of Small and Medium Enterprises in Agribusiness. Jakarta.

Narver, J.C., \& Slater, S.F. (1990). The effect of market orientation on business profitability. Journal of Marketing, 54, 20-35. doi:10.2307/1251757, http://dx.doi.org/10.2307/1251757

Parilli, M.D., \& Elola, A. (2011). The Strenght of Science and Technology Drivers for SME Innovation. Small Business Economics. doi:10.1007/s11187-011-9319-6, http://dx.doi.org/10.1007/s11187-011-9319-6

Pelham, A.M. (1997). Mediating Influences on the Relationship between Market Orientation and Profitability in Small Industrial Firms. Journal of Marketing Theory and Practice, 5(2), 1-23.

Pelham, A.M., \& D.T. Wilson. (1996). A Longitudinal Study of the Impact of Market Structure, Firm Structure, Strategy, and Market Orientation Culture on Dimensions of Small Firm Performance. Journal of the Academy of Marketing Science, 24(1), 7-43. doi:10.1007/BF02893935, http://dx.doi.org/10.1007/BF02893935

Porter M. (1990). The competitive Advantage of Nations. Macmilan, London.

Porter, M. E. (2008). On Competition; Update and Expanded Edition. USA: Hardvard Business Press.

Rama, R. (1996). Empirical Study on Sources of Innovation in International Food and Beverage Industry. Agribusiness, 12(2), 123-134. doi:10.1002/(SICI)1520-6297(199603/04)12:2<123::AID-AGR2>3.0.CO;2-4, http://dx.doi.org/10.1002/(SICI)1520-6297(199603/04)12:2<123::AID-AGR2>3.0.CO;2-4

Raymond, L., \& St-Pierre, J. (2010). R\&D as a Determinant of Innovation in Manufacturing SMEs: An Attempt at Empirical Clarification. Technovation, 30(1), 48-56. doi:10.1016/j.technovation.2009.05.005, http://dx.doi.org/10.1016/j.technovation.2009.05.005

Salavou, H. (2002). Profitability in Market-Oriented SMEs: Does Product Innovation Matter? European Journal of Innovation Management, 5(3), 164-171. doi:10.1108/14601060210436736, http://dx.doi.org/10.1108/14601060210436736 
Sato, Y. (2000). Linkage Formation by Small Firms: The Case of a Rural Cluster in Indonesia. Bulletin of Indonesian Economic Studies, 31, 529-566.

Slater, S.F., \& J.C. Narver. (1994). Does Competitive Environment Moderate the Market Orientation-Performance Relationship? Journal of Marketing, 58, 46-55. doi:10.2307/1252250, http://dx.doi.org/10.2307/1252250

Stuart, C. (1979). Search and Spatial Organization of Trading. In S. Lippman \& J. McCall (Eds.), Studies in the Economics of Search. Amsterdam: North-Holland.

Sundbo, J. (2003). Innovation and strategic reflexivity: An evolutionary approach applied to service. In The International Handbook on Innovation.

Tambunan, T. (2005). Promoting Small and Medium Enterprises with a Clustering Approach: A Policy Experience from Indonesia. Journal of Small Business Management, 43(2), 138-154. doi:10.1111/j.1540-627X.2005.00130.x, http://dx.doi.org/10.1111/j.1540-627X.2005.00130.x

Tambunan, T. (2008). Development of Rural Manufacturing SME Clusters in a Developing Country: The Indonesian Case. Journal of Rural Development, 31(2), 123-146.

Verhees, Frans J.H.M., \& Meulenberg, M.T.G. (2004). Market Orientation, Innovativeness, Product Innovation, and Performance in Small Firms. Journal of Small Business Management, 42(2), 134-154. doi:10.1111/j.1540-627X.2004.00102.x, http://dx.doi.org/10.1111/j.1540-627X.2004.00102.x

Von Hippel E. (1988). Sources of Innovation. Oxford University Press, New York.

Waits, M. J. (2000). The Added Value of the Industry Cluster Approach to Economic Analysis, Strategy Development, and Service Delivery. Economic Development Quarterly, 14(1), 35-50. doi:10.1177/089124240001400106, http://dx.doi.org/10.1177/089124240001400106

Wang, C-H., Chen, K-Y., \& Chen, S-C. (2011). Total Quality Management, Market Orientation and Hotel Performance: The Moderating Effects of External Environmental Factors. International Journal of Hospitality Management. doi:10.1016/i.ijhm.2011.03.013, http://dx.doi.org/10.1016/ i.ijhm.2011.03.013

Yingming, Z. (2010). Analysis of Industrial Clusters in China. USA: Science Press.

Table 1. Comparison of performance between clustered and dispersed SMEs

\begin{tabular}{|l|c|c|c|c|}
\hline Variable & $\begin{array}{c}\text { cluster } \\
\text { Performance }\end{array}$ & $\begin{array}{c}\text { non cluster } \\
\text { Mean (Std. Dev.) }\end{array}$ & $\begin{array}{c}\text { Difference } \\
\text { Mean (Std. Dev.) }\end{array}$ & t-value \\
\cline { 1 - 4 } - Sales & $3.47(0.747)$ & $3.08(0.889)$ & $0.38(0.035)$ & 2.558 \\
\hline - Market share & $3.52(0.770)$ & $3.20(0.917)$ & $0.317(0.043)$ & 2.049 \\
\hline - Profit & $3.47(0.853)$ & $3.05(0.891)$ & $0.41(0.043)$ & 2.616 \\
\hline
\end{tabular}

Table 2. Comparison of market orientation and innovation

\begin{tabular}{|l|c|c|c|c|}
\hline Variable & $\begin{array}{c}\text { cluster } \\
\text { Mean (Std. Dev.) }\end{array}$ & $\begin{array}{c}\text { non cluster } \\
\text { Mean (Std. Dev.) }\end{array}$ & $\begin{array}{c}\text { Difference } \\
\text { Mean diff. (p-value) }\end{array}$ & t-value \\
\hline Market Orientation & & & & \\
\hline • Customers Orientation & $3.48(0.890)$ & $3.11(0.882)$ & $0.37(0.023)$ & 2.300 \\
\hline - Competitors Orientation & $3.60(0.907)$ & $3.17(0.951)$ & $0.43(0.012)$ & 2.552 \\
\hline - Internal Coordination & $4.06(0.928)$ & $3.79(0.889)$ & $0.26(0.111)$ & 1.607 \\
\hline Innovation & & & & \\
\hline - Product Innovation & $2.93(0.954)$ & $2.58(0.944)$ & $0.35(0.046)$ & 2.020 \\
\hline - Process Innovation & $2.62(0.846)$ & $2.27(0.936)$ & $0.35(0.034)$ & 2.149 \\
\hline - Marketing Innovation & $3.37(0.736)$ & $3.03(0.901)$ & $0.34(0.028)$ & 2.219 \\
\hline
\end{tabular}




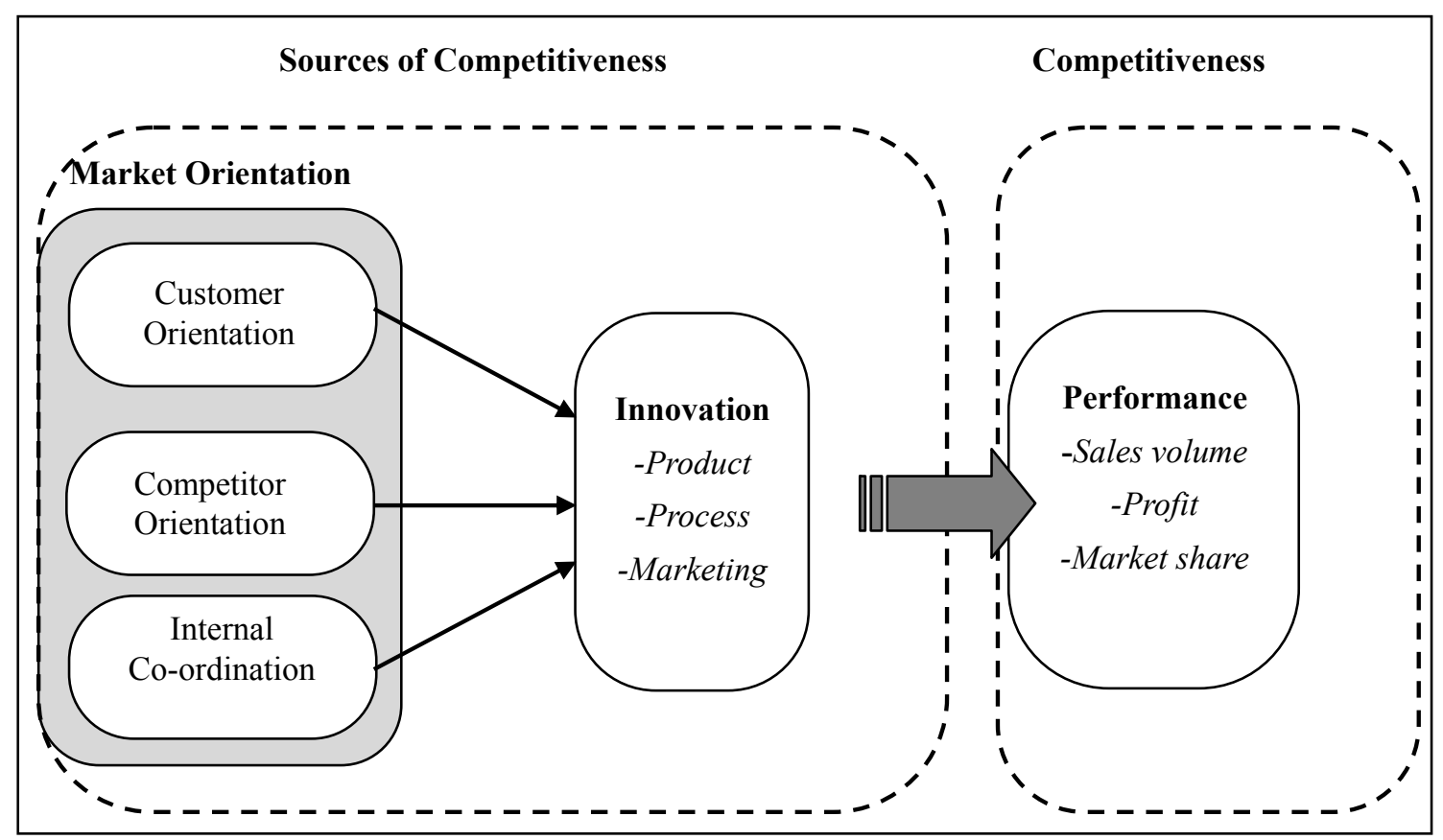

Figure 1. Market orientation, innovation and performance as a model of competitiveness

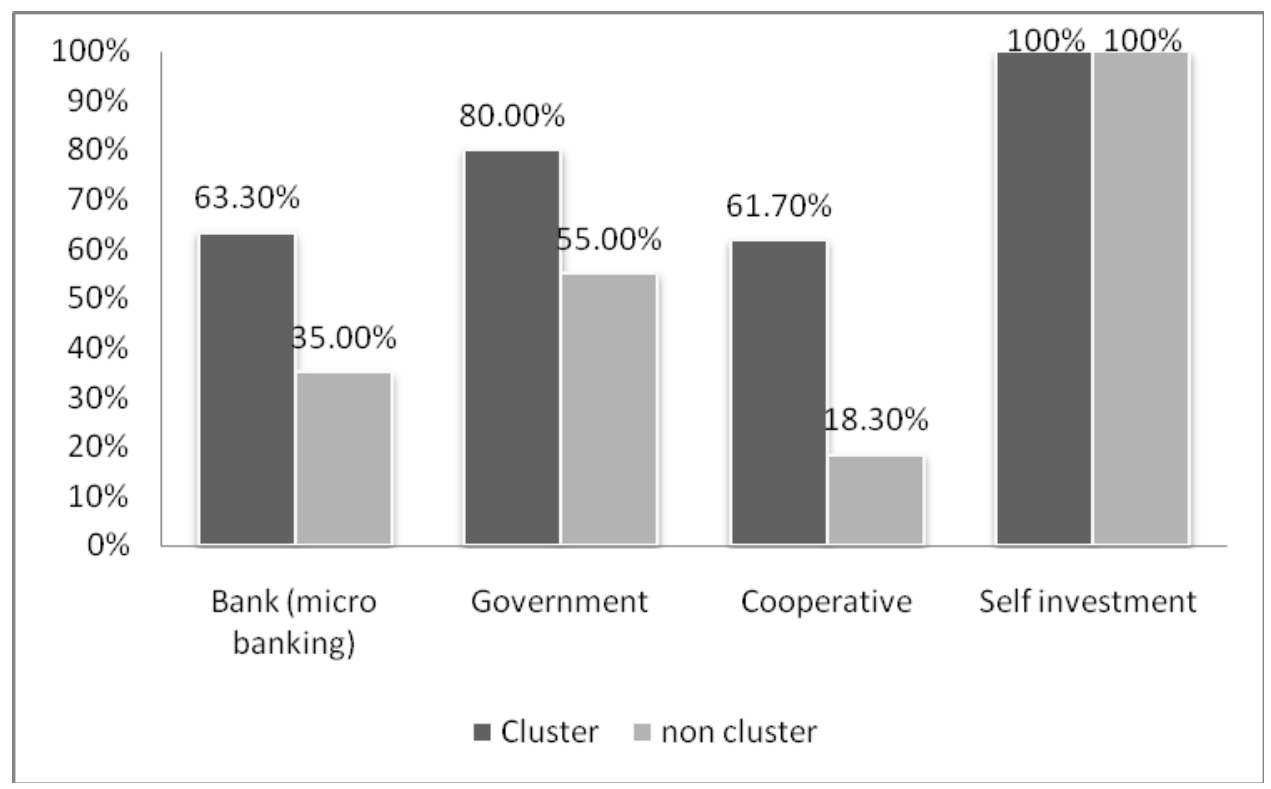

Figure 2. Sources of working capital

Note: $-\mathrm{N}$ cluster $=60, \mathrm{~N}$ non cluster $=60$

-respondent could answer more than one choice 


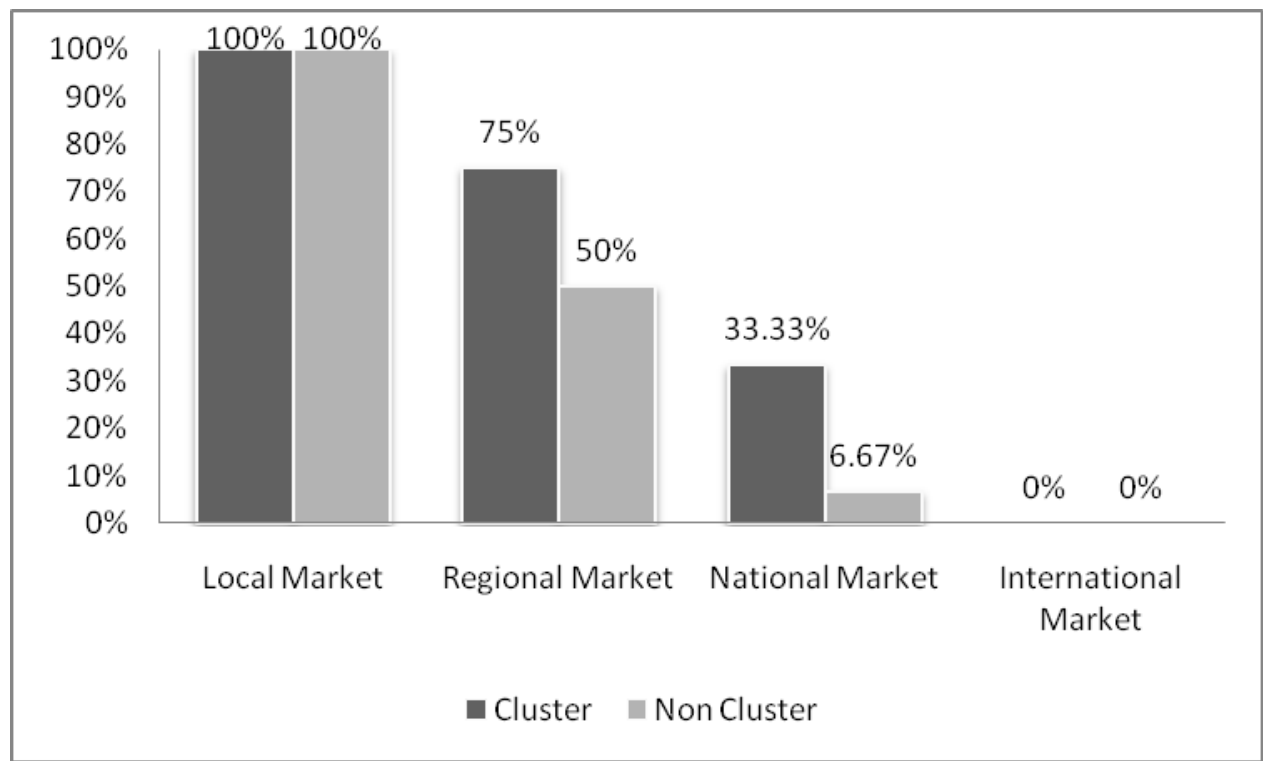

Figure 3. Marketing area

Note: $\quad-\mathrm{N}$ cluster $=60, \mathrm{~N}$ non cluster $=60$

-respondent could answer more than one choice

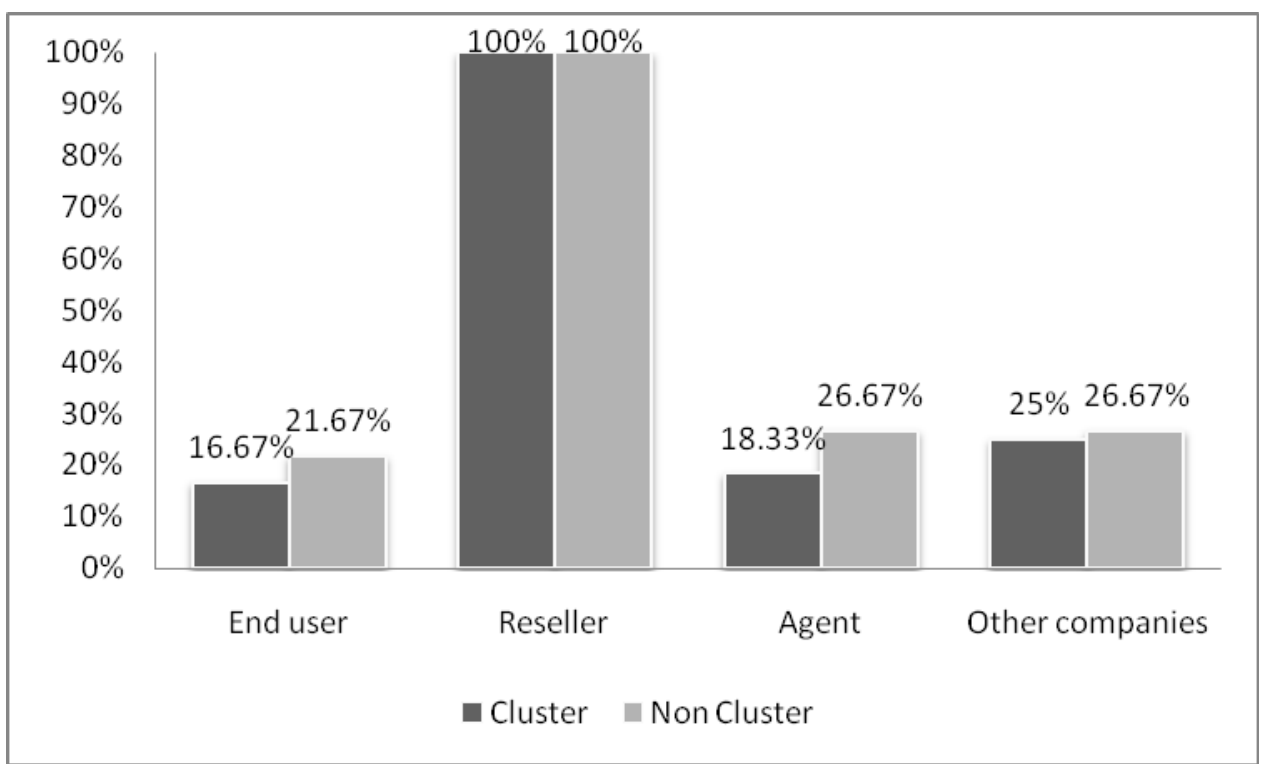

Figure 4. Type of customer

Note: $\quad-\mathrm{N}$ cluster $=60, \mathrm{~N}$ non cluster $=60$

-respondent could answer more than one choice 